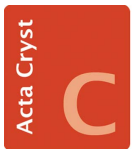

STRUCTURAL

CHEMISTRY

ISSN 2053-2296

Received 4 February 2020

Accepted 31 March 2020

Edited by M. Gardiner, Australian National University, Australia

Keywords: sulfite; $\mathrm{O}-\mathrm{H}$...S hydrogen bonding; crystal structure; crystal chemistry; hepta-

hydrate; structural similarity.

CCDC reference: 1993827

Supporting information: this article has supporting information at journals.iucr.org/C

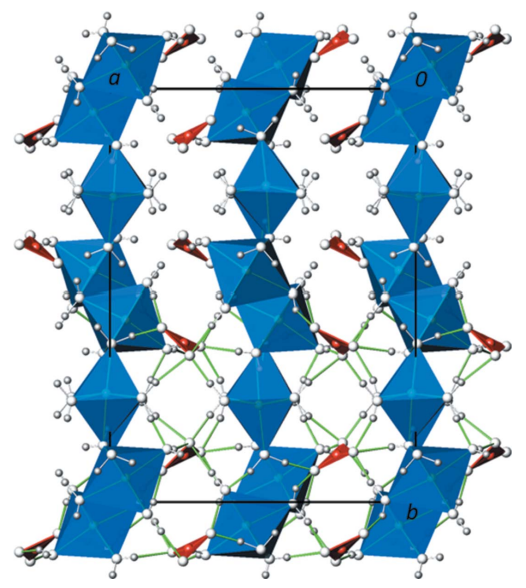

OPEN $\odot$ ACCESS

\section{Sodium sulfite heptahydrate and its relation to sodium carbonate heptahydrate}

\author{
Matthias Weil* and Kurt Mereiter
}

Institute for Chemical Technologies and Analytics, Division of Structural Chemistry, TU Wien, Getreidemarkt 9/164-SC, A-1060 Vienna, Austria. *Correspondence e-mail: matthias.weil@tuwien.ac.at

The monoclinic crystal structure of $\mathrm{Na}_{2} \mathrm{SO}_{3}\left(\mathrm{H}_{2} \mathrm{O}\right)_{7}$ is characterized by an alternating stacking of (100) cationic sodium-water layers and anionic sulfite layers along [100]. The cationic layers are made up from two types of $\left[\mathrm{Na}\left(\mathrm{H}_{2} \mathrm{O}\right)_{6}\right]$ octahedra that form linear ${ }_{\infty}^{1}\left[\mathrm{Na}\left(\mathrm{H}_{2} \mathrm{O}\right)_{4 / 2}\left(\mathrm{H}_{2} \mathrm{O}\right)_{2 / 1}\right]$ chains linked by dimeric $\left[\mathrm{Na}\left(\mathrm{H}_{2} \mathrm{O}\right)_{2 / 2}\left(\mathrm{H}_{2} \mathrm{O}\right)_{4 / 1}\right]_{2}$ units on both sides of the chains. The isolated trigonal-pyramidal sulfite anions are connected to the cationic layers through an intricate network of $\mathrm{O}-\mathrm{H} \cdots \mathrm{O}$ hydrogen bonds, together with a remarkable $\mathrm{O}-\mathrm{H} \cdots \mathrm{S}$ hydrogen bond, with an $\mathrm{O} \cdots \mathrm{S}$ donor-acceptor distance of 3.2582 (6) $\AA$, which is about $0.05 \AA$ shorter than the average for $\mathrm{O}-\mathrm{H} \cdots \mathrm{S}$ hydrogen bonds in thiosalt hydrates and organic sulfur compounds of the type $Y-\mathrm{S}-Z(Y / Z=\mathrm{C}, \mathrm{N}, \mathrm{O}$ or $\mathrm{S})$. Structural relationships between monoclinic $\mathrm{Na}_{2} \mathrm{SO}_{3}\left(\mathrm{H}_{2} \mathrm{O}\right)_{7}$ and orthorhombic $\mathrm{Na}_{2} \mathrm{CO}_{3}\left(\mathrm{H}_{2} \mathrm{O}\right)_{7}$ are discussed in detail.

\section{Introduction}

Sodium sulfite is used extensively in industrial processes, for example, as an antioxidant and preservative in food industries (E number for food additives E221), as a corrosion inhibitor in aqueous media, as a bleaching agent, as a solubilizing agent for cellulose, straw and wood in the pulp and paper industry, or as an additive in dying processes. In the USA alone, the production of sodium sulfite reached 150000 tons in 2002 (Weil et al., 2007). Solid sodium sulfite is stable in its anhydrous form and as the heptahydrate. Despite its use at industrial scales, structural details are known only for anhydrous $\mathrm{Na}_{2} \mathrm{SO}_{3}$ that crystallizes with two formula units in the trigonal system in the space group $P \overline{3}$ (Larsson \& Kierkegaard, 1969). Bond lengths and near-neighbour distances of sodium sulfite in aqueous solution have been calculated by $a b$ initio quantum mechanical charge field molecular dynamics (QMCF MD) studies and determined experimentally by largeangle X-ray scattering (LAXS) by Eklund et al. (2012). For crystalline $\mathrm{Na}_{2} \mathrm{SO}_{3}\left(\mathrm{H}_{2} \mathrm{O}\right)_{7}$, lattice parameters and the space group $\left(P 2_{1} / n\right)$ have previously been determined from Weissenberg photographs without providing further structural details, except for a close metrical resemblance with orthorhombic $\mathrm{Na}_{2} \mathrm{CO}_{3}\left(\mathrm{H}_{2} \mathrm{O}\right)_{7}$ (Dunsmore \& Speakman, 1963). To obtain a more detailed picture of the relationship between the heptahydrates of $\mathrm{Na}_{2} \mathrm{SO}_{3}$ and $\mathrm{Na}_{2} \mathrm{CO}_{3}$, we grew single crystals of $\mathrm{Na}_{2} \mathrm{SO}_{3}\left(\mathrm{H}_{2} \mathrm{O}\right)_{7}$ and determined its crystal structure. Indeed, the two heptahydrates show not only a close metrical relationship (Table 1), but also structural similarities, though they belong to different crystal systems and contain differently shaped divalent anions, viz. trigonal-pyramidal $\mathrm{SO}_{3}{ }^{2-}$ and trigonal-planar $\mathrm{CO}_{3}{ }^{2-}$. 
Table 1

Comparison of lattice parameters $\left(\AA{ }^{\circ}\right.$, for $\mathrm{Na}_{2} \mathrm{SO}_{3}\left(\mathrm{H}_{2} \mathrm{O}\right)_{7}$ (this work) and $\mathrm{Na}_{2} \mathrm{CO}_{3}\left(\mathrm{H}_{2} \mathrm{O}\right)_{7}$ (Betzel et al., 1982).

\begin{tabular}{lll}
\hline & $\mathrm{Na}_{2} \mathrm{SO}_{3}\left(\mathrm{H}_{2} \mathrm{O}\right)_{7}$ & $\mathrm{Na}_{2} \mathrm{CO}_{3}\left(\mathrm{H}_{2} \mathrm{O}\right)_{7}$ \\
\hline$a$ & $14.6563(8)$ & $14.492(7)$ \\
$b$ & $19.7180(9)$ & $19.490(5)$ \\
$c$ & $7.2197(5)$ & $7.017(3)$ \\
$\alpha$ & 90 & 90 \\
$\beta$ & 90 & 90 \\
$\gamma$ & $94.0997(17)$ & 90 \\
$V\left(\AA^{3}\right)$ & $2081.1(2)$ & 1981.95 \\
$T(\mathrm{~K})$ & 100 & $\mathrm{RT}$ \\
Space group & $C 112_{1} / a$ & $P b c a$ \\
\hline
\end{tabular}

\section{Experimental}

\subsection{Crystallization}

Colourless prismatic crystals of $\mathrm{Na}_{2} \mathrm{SO}_{3}\left(\mathrm{H}_{2} \mathrm{O}\right)_{7}$ were grown by recrystallization of a commercial anhydrous sample (Merck, p.A. grade) from an aqueous solution at room temperature by slow evaporation over the course of several days. In order to remove adherent mother liquor, the crystals were placed on filter paper and subsequently immersed in Paratone oil. The crystal under investigation was cleaved from a larger specimen.

\subsection{Crystallography and refinement}

Crystal data, data collection and structure refinement details are summarized in Table 2. The crystal structure of $\mathrm{Na}_{2} \mathrm{SO}_{3}\left(\mathrm{H}_{2} \mathrm{O}\right)_{7}$ was originally solved and refined in the space group $P 12_{1} / n 1$ (No. 14), with lattice parameters $a=$ $11.8576(8), b=7.2197(5), c=12.6965(9) \AA$ and $\beta=$ $106.7938(17)^{\circ}$ at $100 \mathrm{~K}$ (full crystal data in the setting $P 12_{1} / n 1$ are available in CIF format as supporting information). The values for the lattice parameters at $100 \mathrm{~K}$ are in good agreement with the previous study, with values of $a=11.922, b=$ 7.260, $c=12.765 \AA$ and $\beta=107.22^{\circ}$ obtained at room temperature from Weissenberg film data (note that $a$ and $c$ are interchanged in the original description; Dunsmore \& Speakman, 1963). For a better comparison with the reported crystal structure of $\beta-\mathrm{Na}_{2} \mathrm{CO}_{3}\left(\mathrm{H}_{2} \mathrm{O}\right)_{7}$ (Betzel et al., 1982), the nonconventional setting $C 112_{1} / a$ was chosen for the final structural description of $\mathrm{Na}_{2} \mathrm{SO}_{3}\left(\mathrm{H}_{2} \mathrm{O}\right)_{7}$, using the matrix (101, $10 \overline{1}, 010)$ for transformation of the primitive cell to the $C$ centred cell with $c$ as the unique axis; moreover, the atomic coordinates and the origin of the unit cell were chosen to ensure a similar packing of structural building blocks in the two unit cells of $\mathrm{Na}_{2} \mathrm{SO}_{3}\left(\mathrm{H}_{2} \mathrm{O}\right)_{7}$ and $\beta-\mathrm{Na}_{2} \mathrm{CO}_{3}\left(\mathrm{H}_{2} \mathrm{O}\right)_{7}$. All $\mathrm{H}$ atoms present in the crystal structure of $\mathrm{Na}_{2} \mathrm{SO}_{3}\left(\mathrm{H}_{2} \mathrm{O}\right)_{7}$ were located in a difference Fourier map and were refined freely.

\section{Results and discussion}

\subsection{Crystal structure}

In the crystal structure of $\mathrm{Na}_{2} \mathrm{SO}_{3}\left(\mathrm{H}_{2} \mathrm{O}\right)_{7}$, all atoms $(2 \mathrm{Na}, 1$ $\mathrm{S}, 10 \mathrm{O}$ and $14 \mathrm{H})$ are located on general sites. The two sodium cations are surrounded by six water molecules, defining a distorted octahedral coordination polyhedron in each case.
Table 2

Experimental details.

\begin{tabular}{|c|c|}
\hline \multicolumn{2}{|l|}{ Crystal data } \\
\hline Chemical formula & $\mathrm{Na}_{2} \mathrm{SO}_{3}\left(\mathrm{H}_{2} \mathrm{O}\right)_{7}$ \\
\hline$M_{\mathrm{r}}$ & 252.15 \\
\hline Crystal system, space group & Monoclinic, $C 112_{1} / a$ \\
\hline Temperature $(\mathrm{K})$ & 100 \\
\hline$a, b, c(\AA)$ & $14.6563(8), 19.7180(9), 7.2197(5)$ \\
\hline$\gamma\left({ }^{\circ}\right)$ & $94.0997(17)$ \\
\hline$V\left(\AA^{3}\right)$ & $2081.1(2)$ \\
\hline$Z$ & 8 \\
\hline Radiation type & Мо $K \alpha$ \\
\hline$\mu\left(\mathrm{mm}^{-1}\right)$ & 0.42 \\
\hline Crystal size $(\mathrm{mm})$ & $0.15 \times 0.13 \times 0.12$ \\
\hline \multicolumn{2}{|l|}{ Data collection } \\
\hline Diffractometer & Bruker APEXII CCD \\
\hline Absorption correction & $\begin{array}{l}\text { Multi-scan (SADABS; Krause et } \\
\text { al., 2015) }\end{array}$ \\
\hline$T_{\min }, T_{\max }$ & $0.675,0.747$ \\
\hline $\begin{array}{l}\text { No. of measured, independent and } \\
\text { observed }[I>2 \sigma(I)] \text { reflections }\end{array}$ & $16909,4845,4222$ \\
\hline$R_{\text {int }}$ & 0.021 \\
\hline$(\sin \theta / \lambda)_{\max }\left(\AA^{-1}\right)$ & 0.827 \\
\hline \multicolumn{2}{|l|}{ Refinement } \\
\hline$R\left[F^{2}>2 \sigma\left(F^{2}\right)\right], w R\left(F^{2}\right), S$ & $0.023,0.063,1.06$ \\
\hline No. of reflections & 4845 \\
\hline No. of parameters & 174 \\
\hline $\mathrm{H}$-atom treatment & All H-atom parameters refined \\
\hline$\Delta \rho_{\max }, \Delta \rho_{\min }\left(\mathrm{e} \AA^{-3}\right)$ & $0.89,-0.33$ \\
\hline
\end{tabular}

Computer programs: APEX2 (Bruker, 2014), SAINT (Bruker, 2014), SHELXT (Sheldrick, 2015a), SHELXL2018 (Sheldrick, 2015b), ATOMS (Dowty, 2006), Mercury (Macrae et al., 2020) and publCIF (Westrip, 2010).

The $\mathrm{Na}-\mathrm{O}$ distances range from 2.3690 (6) to 2.4952 (6) $\AA$ (Table 3), with mean values of $2.42(4) \AA$ for $\mathrm{Na} 1$ and 2.43 (6) $\AA$ for $\mathrm{Na} 2$, in fairly good agreement with the mean value for $\mathrm{Na}^{[6]}-\mathrm{O}$ of 2.44 (11) $\AA$ calculated for 5520 individual bonds (Gagné \& Hawthorne, 2016). The bond valence sums (Brown, 2002) for the sodium cations, as calculated with parameters provided by Brese \& O'Keeffe (1991), are 1.15 valence units (v.u.) for $\mathrm{Na} 1$ and 1.13 v.u. for $\mathrm{Na} 2$, and thus in the expected range for monovalent $\mathrm{Na}^{+}$. The $\mathrm{O}-\mathrm{Na}-\mathrm{O}$ angles deviate clearly from ideal values, with values for trans $\mathrm{O}$ atoms in the range $172.149(16)-176.42(2)^{\circ}$ for $\mathrm{Na} 1$ and 165.81 (2) $-174.23(2)^{\circ}$ for $\mathrm{Na} 2$, and for cis $\mathrm{O}$ atoms in the range $81.464(19)-101.74(2)^{\circ}$ for $\mathrm{Na} 1$ and $81.51(2)-$ $103.23(2)^{\circ}$ for $\mathrm{Na} 2$. The two types of $\left[\mathrm{Na}\left(\mathrm{H}_{2} \mathrm{O}\right)_{6}\right]$ octahedra show a different linkage pattern. Octahedra centred by $\mathrm{Na} 1$ share common edges $\left(\mathrm{O} 8 / \mathrm{O} 10\right.$ and $\mathrm{O} 8{ }^{\mathrm{ii}} / \mathrm{O} 10^{\mathrm{i}}$; see Table 3 for symmetry codes) to form infinite linear ${ }_{\infty}^{1}\left[\mathrm{Na} 1\left(\mathrm{H}_{2} \mathrm{O}\right)_{4 / 2}\left(\mathrm{H}_{2} \mathrm{O}\right)_{2 / 1}\right]$ chains running parallel to [001], whereas octahedra centred by $\mathrm{Na} 2$ make up dimeric $\left[\mathrm{Na} 2\left(\mathrm{H}_{2} \mathrm{O}\right)_{2 / 2}\left(\mathrm{H}_{2} \mathrm{O}\right)_{4 / 1}\right]_{2}$ units by sharing an edge ( $\mathrm{O} 5$ and $\left.\mathrm{O}^{\mathrm{iii}}\right)$. In both cases, the corresponding $\mathrm{Na}-$ $\mathrm{O}$ bonds to the shared $\mathrm{O}$ atoms at the edges are the shortest in the respective octahedron. The dimeric units connect adjacent chains by sharing the terminal water molecules (O9 and $\mathrm{O} 7$ ) on both sides of the chains (corner-sharing links). This way, the sodium-water octahedra are assembled by edge- and cornersharing into an infinite layer extending parallel to (100) (Fig. 1a).

The sulfite anion has the characteristic trigonal-pyramidal configuration, with the $\mathrm{S}^{\mathrm{IV}}$ atom occupying the pyramidal 
position. Atom S1 is 0.5912 (4) $\AA$ above the basal plane formed by atoms $\mathrm{O} 1, \mathrm{O} 2$ and $\mathrm{O} 3$. The $\mathrm{S}-\mathrm{O}$ bond lengths are in a narrow range 1.5224 (5)-1.5338 (5) $\AA$ [mean 1.527 (6) $\AA$ ] , just like the $\mathrm{O}-\mathrm{S}-\mathrm{O}$ angles $\left[105.85(3)-106.07(3)^{\circ}\right.$; mean $\left.105.93(16)^{\circ}\right]$. Again, these values are in good agreement with the grand mean $\mathrm{S}^{\mathrm{IV}}-\mathrm{O}$ bond length of 1.529 (15) $\AA$ calculated for 90 bonds and with the $\mathrm{O}-\mathrm{S}^{\mathrm{IV}}-\mathrm{O}$ angles in the range $\sim 99-107^{\circ}$ with a mean value of $\sim 104^{\circ}$ (Gagné \& Hawthorne, 2018). The bond valence sum for atom $S 1$ is 4.12 v.u., using the parameters of Brese \& O'Keeffe (1991) for calculation. The sulfite anions are isolated from the sodium-water layer, lying alternatingly on both sides outside of an individual layer. In this way, cationic sodium-water layers at $x \simeq 0, \frac{1}{2}$ are sandwiched by sulfite layers at $x \simeq \frac{1}{4}, \frac{3}{4}$ and stacked along [100], with the sulfite anions situated approximately at the height in $y$ where the $\left[\mathrm{Na}_{2} \mathrm{O}_{2 / 2} \mathrm{O}_{4 / 1}\right]_{2}$ dimers are linked to the ${ }_{\infty}^{1}[\mathrm{Na} 1-$ $\left.\left(\mathrm{H}_{2} \mathrm{O}\right)_{4 / 2}\left(\mathrm{H}_{2} \mathrm{O}\right)_{2 / 1}\right]$ chains (Fig. 2a).

The seven independent water molecules possess approximately tetrahedral coordination arrangements (including hydrogen bonds), except for $\mathrm{O} 9$, and five of them each bridge two sodium cations $(\mathrm{O} 5, \mathrm{O} 7, \mathrm{O} 8, \mathrm{O} 9$ and $\mathrm{O} 10)$, whereas two are each bonded to only one sodium cation (O4 and $\mathrm{O} 6)$. An intricate network of $\mathrm{O}-\mathrm{H} \cdots \mathrm{O}$ hydrogen bonds between the water molecules and the sulfite $\mathrm{O}$ atoms link the anionic layers to adjacent cationic layers, thus establishing a three-dimensional hydrogen-bonded network structure (Fig. 2a). Based on
Table 3

Selected geometric parameters $\left(\AA{ }^{\circ}\right)$.

\begin{tabular}{llll}
\hline $\mathrm{Na} 1-\mathrm{O} 10$ & $2.3690(6)$ & $\mathrm{Na} 2-\mathrm{O} 4$ & $2.3939(6)$ \\
$\mathrm{Na} 1-\mathrm{O} 8$ & $2.3785(6)$ & $\mathrm{Na} 2-\mathrm{O} 7$ & $2.4093(6)$ \\
$\mathrm{Na} 1-\mathrm{O} 10^{\mathrm{i}}$ & $2.4199(6)$ & $\mathrm{Na} 2-\mathrm{O} 6$ & $2.4928(6)$ \\
$\mathrm{Na} 1-\mathrm{O} 7$ & $2.4199(6)$ & $\mathrm{Na}-\mathrm{O} 9^{\mathrm{i}}$ & $2.4952(6)$ \\
$\mathrm{Na} 1-\mathrm{O} 8^{\mathrm{ii}}$ & $2.4436(6)$ & $\mathrm{S} 1-\mathrm{O} 3$ & $1.5224(5)$ \\
$\mathrm{Na} 1-\mathrm{O} 9$ & $2.4599(6)$ & $\mathrm{S} 1-\mathrm{O} 1$ & $1.5234(5)$ \\
$\mathrm{Na} 2-\mathrm{O} 5^{\mathrm{iii}}$ & $2.3787(6)$ & $\mathrm{S} 1-\mathrm{O} 2$ & $1.5338(5)$ \\
$\mathrm{Na} 2-\mathrm{O} 5$ & $2.3805(6)$ & & \\
$\mathrm{O} 3-\mathrm{S} 1-\mathrm{O} 1$ & $105.85(3)$ & $\mathrm{O} 1-\mathrm{S} 1-\mathrm{O} 2$ & $105.87(3)$ \\
$\mathrm{O} 3-\mathrm{S} 1-\mathrm{O} 2$ & $106.07(3)$ & & \\
\hline
\end{tabular}

Symmetry codes: (i) $-x+1,-y+\frac{1}{2}, z+\frac{1}{2}$; (ii) $-x+1,-y+\frac{1}{2}, z-\frac{1}{2}$; (iii) $-x+1$, $-y,-z+3$.

the donor-acceptor distances between 2.7204 (7) and 2.9110 (8) $\AA$ (Table 4), the hydrogen-bonding strength is moderate according to the classification of Jeffrey (1997). Most of these hydrogen bonds are donated to sulfite atoms $\mathrm{O} 1, \mathrm{O} 2$ and $\mathrm{O} 3$ (Fig. 3a). Thereby, atom $\mathrm{O} 1$ is the acceptor of three, $\mathrm{O} 2$ of four and $\mathrm{O} 3$ of three hydrogen bonds. It is worth noting that the $\mathrm{S}-\mathrm{O}$ bond lengths reflect this situation nicely, with $\mathrm{S} 1-\mathrm{O} 2=1.5338$ (5) $\AA$ being about $0.01 \AA$ longer than the remaining two. The $\mathrm{O} 9$ water molecule, bonded to Na1, $\mathrm{Na} 2$ and via $\mathrm{H} 9 A$ to $\mathrm{O} 2$, lacks a clearcut hydrogen bond for its second $\mathrm{H}$ atom $(\mathrm{H} 9 B)$, which points to $\mathrm{H} 6 B$ of the O6$\mathrm{H} 6 B \cdots \mathrm{O} 3$ hydrogen bond $\left[\mathrm{H} 9 B\left(x, y-\frac{1}{2}, z+\frac{5}{2}\right) \cdots \mathrm{H} 6 B=\right.$

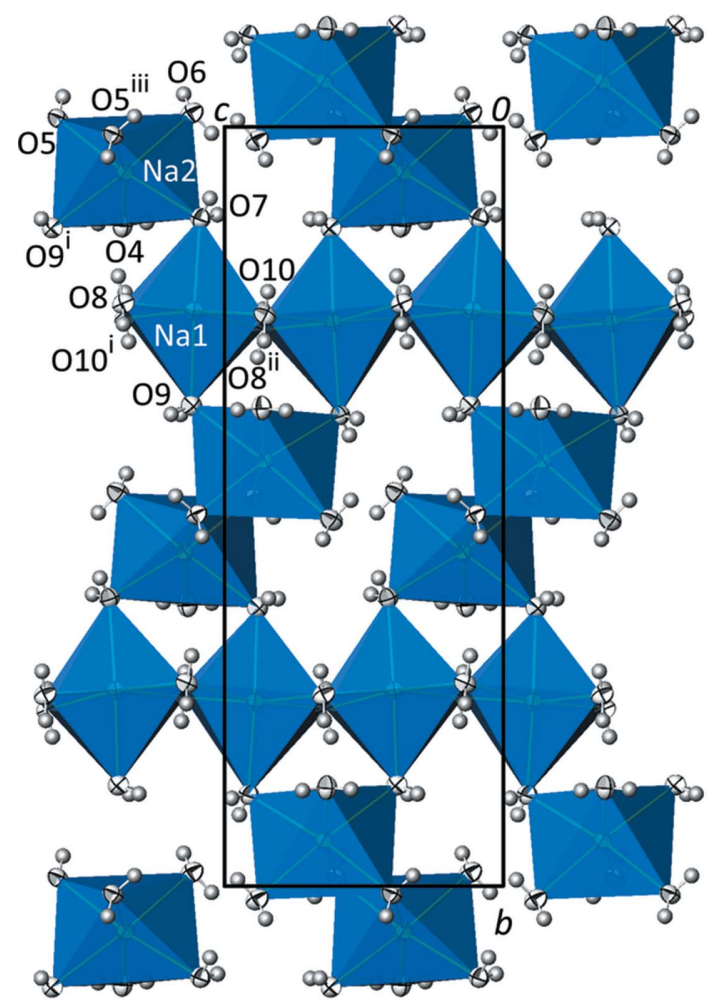

(a)

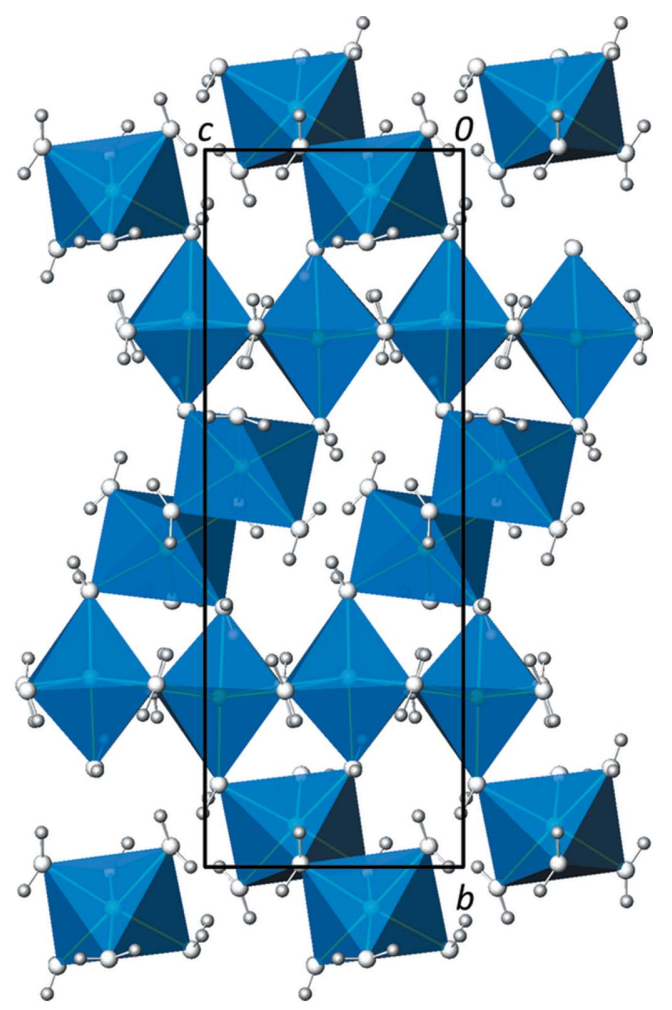

(b)

Figure 1

(a) View along [100] onto the cationic water-sodium (100) layer in the crystal structure of $\mathrm{Na}_{2} \mathrm{SO}_{3}\left(\mathrm{H}_{2} \mathrm{O}\right)_{7}$ made up from edge- and corner-sharing $\left[\mathrm{Na}\left(\mathrm{H}_{2} \mathrm{O}\right)_{6}\right]$ octahedra (turquoise). Anisotropic displacement ellipsoids are drawn at the $90 \%$ probability level and $\mathrm{H}$ atoms are shown as grey spheres of arbitrary radii. Symmetry codes refer to Table 3. (b) The same type of layer in the crystal structure of $\mathrm{Na}_{2} \mathrm{CO}_{3}\left(\mathrm{H}_{2} \mathrm{O}\right)_{7}$, with atoms as spheres of arbitrary radii. 
$2.49 \AA$ ] , while distances from $\mathrm{O} 9\left(x, y-\frac{1}{2}, z+\frac{5}{2}\right)$ to $\mathrm{O} 6$ and $\mathrm{O} 3$ exceed $3.3 \AA$.

In addition to the interactions between water molecules and sulfite $\mathrm{O}$ atoms, there are two hydrogen bonds between water molecules only $\left(\mathrm{O} 7 \cdots \mathrm{O}^{\mathrm{vi}}\right.$ and $\mathrm{O} 10 \cdots \mathrm{O} 4^{\mathrm{ii}}$; symmetry codes refer to Table 4), and, as a pecularity, an $\mathrm{O}-\mathrm{H} \cdots \mathrm{S}$ hydrogen bond between $\mathrm{O} 8$ and $\mathrm{S}^{\text {vii }}$. In general, $\mathrm{S} \cdots \mathrm{H}$ interactions involving divalent $\mathrm{S}$ atoms are considered as weak hydrogen bonds (Allen et al., 1997). The H...S hydrogen-bonding strength becomes even weaker for $\mathrm{H} \cdots \mathrm{SO}_{3}$ contacts because the $\mathrm{S}$ atom is positively polarized in an $\mathrm{SO}_{3}{ }^{2-}$ anion with partial double-bond character for the $\mathrm{S}-\mathrm{O}$ bonds (Nyberg \& Larsson, 1973). The hydrogen-bond acceptor ability of divalent sulfur was evaluated some time ago from 1811 substructures of mostly organic compounds, i.e. $Y-\mathrm{S}-Z$ systems $(Y / Z=\mathrm{C}, \mathrm{N}, \mathrm{O}$ or $\mathrm{S})$ as acceptor groups retrieved from the Cambridge Structural Database, giving a mean intermolecular $>\mathrm{S} \cdots \mathrm{H}$ distance of $2.67(5) \AA$ for $\mathrm{O}-\mathrm{H}$ donors and a mean S. . O distance of 3.39 (4) $\AA$ (Allen et al., 1997; Groom et al., 2016). In comparison, the first ever reported crystal structure determination of an inorganic compound with an $\mathrm{O}-\mathrm{H} \cdots \mathrm{S}$ hydrogen bond and a clear location of the $\mathrm{H}$ atoms, viz. $\mathrm{BaS}_{2} \mathrm{O}_{3}\left(\mathrm{H}_{2} \mathrm{O}\right)$ from neutron single-crystal diffraction data (Manojlović-Muir, 1969), revealed a considerably shorter S...H distance of 2.367 (4) $\AA$ and a likewise shorter S...O distance of 3.298 (4) $\AA$. The $\mathrm{O}-\mathrm{H} \cdots \mathrm{S}$ angle in $\mathrm{BaS}_{2} \mathrm{O}_{3} \cdot \mathrm{H}_{2} \mathrm{O}$ was determined as $163(3)^{\circ}$. Corresponding values of the $\mathrm{O}-$ $\mathrm{H} \cdots \mathrm{S}$ hydrogen bond in the crystal structure of $\mathrm{Na}_{2} \mathrm{SO}_{3}$ $\left(\mathrm{H}_{2} \mathrm{O}\right)_{7}$ are somewhat larger at $2.455(14) \AA$ for $\mathrm{H} 8 B \cdots \mathrm{S}^{\mathrm{vii}}$ (X-ray data), slightly shorter at 3.2582 (6) $\AA$ for O8 $\cdots \mathrm{S} 1^{\mathrm{vii}}$ and
Table 4

Hydrogen-bond geometry $\left(\AA{ }^{\circ}\right)$.

\begin{tabular}{|c|c|c|c|c|}
\hline$D-\mathrm{H} \cdots A$ & $D-\mathrm{H}$ & $\mathrm{H} \cdots A$ & $D \cdots A$ & $D-\mathrm{H} \cdots A$ \\
\hline $4-\mathrm{H} 4 A \cdots \mathrm{O} 3^{\mathrm{iv}}$ & $0.800(15)$ & $2.031(16)$ & $2.8216(8)$ & $169.7(15)$ \\
\hline $4-\mathrm{H} 4 B \cdots \mathrm{O} 1^{\mathrm{v}}$ & 821 & 983 & 2700 & $167.8(15)$ \\
\hline $5-\mathrm{H} 5 A \cdots \mathrm{O} 1$ & 04 & 947 & 2.7503 & $175.9(13)$ \\
\hline $\mathrm{D} 5-\mathrm{H} 5 B \cdots \mathrm{O} 2^{\mathrm{iv}}$ & 798 & 1.994 & 2.7694 & $163.9(15)$ \\
\hline $\mathrm{O} 6-\mathrm{H} 6 A \cdots \mathrm{O} 2^{\mathrm{v}}$ & 777( & 2.072 & $2.8206(7)$ & $161.8(14)$ \\
\hline $26-\mathrm{H} 6 R \ldots \mathrm{O}$ & 774 & & & $.5(15)$ \\
\hline .. & & & ) & $169.3(13)$ \\
\hline $\mathrm{D} 7-\mathrm{H} 7 \mathrm{~B} \cdots \mathrm{C}$ & & 2.17 & ) & $.7(15)$ \\
\hline $\mathrm{O} 8-\mathrm{H} 8 A \cdots \mathrm{O} 1^{\mathrm{iii}}$ & 0.792 & $2.009(15)$ & $2.7900(7)$ & $168.9(13)$ \\
\hline $\mathrm{O} 8-\mathrm{H} 8 B \cdots \mathrm{S} 1^{\mathrm{vii}}$ & $0.825(14)$ & $2.455(14)$ & $3.2582(6)$ & $164.5(13)$ \\
\hline $\mathrm{O} 9-\mathrm{H} 9 A \cdots \mathrm{O} 2^{\mathrm{vii}}$ & $.807(14)$ & 2.106 & $2.9096(7)$ & $174.0(14)$ \\
\hline & & & & \\
\hline $\mathrm{O} 10-\mathrm{H} 10 B \cdots \mathrm{O}$ & $0.762(14)$ & 2.069( & $2.8210(7)$ & $169.1(14)$ \\
\hline
\end{tabular}

Symmetry codes: (ii) $-x+1,-y+\frac{1}{2}, z-\frac{1}{2}$; (iii) $-x+1,-y,-z+3$; (iv) $-x+\frac{3}{2},-y, z+\frac{1}{2}$; (v) $-x+\frac{3}{2},-y, z-\frac{1}{2}$; (vi) $-x+1,-y,-z+2$; (vii) $x-\frac{1}{2}, y+\frac{1}{2}, z$.

similar at $164.5(13)^{\circ}$ for the $\mathrm{O} 8-\mathrm{H} 8 B \cdots \mathrm{S} 1^{\mathrm{vii}}$ angle. A comparable $\mathrm{O} \cdots \mathrm{S}$ distance of $3.326 \AA$ was found as the mean value for 86 hydrogen-bonding interactions between water molecules and $\mathrm{S}$ atoms in a variety of thiosalt hydrates, such as Schlippes salt, $\mathrm{Na}_{3} \mathrm{SbS}_{4}\left(\mathrm{H}_{2} \mathrm{O}\right)_{9}$ (Mikenda et al., 1989). A literature search indicated that the $\mathrm{O}-\mathrm{H} \cdots \mathrm{S}$ hydrogen bond in the title compound appears to be unprecedented thus far among hydrated sulfites. This suggests that in sulfite hydrates, $\mathrm{O}-\mathrm{H} \cdots \mathrm{O}$ hydrogen bonding is clearly preferred over $\mathrm{O}-$ $\mathrm{H}$...S hydrogen bonding and that a certain structural motif is needed to induce $\mathrm{O}-\mathrm{H} \cdots \mathrm{S}$ hydrogen bonding like in the title compound. Invoking the results of an electron deformation density study of $\mathrm{MgSO}_{3}\left(\mathrm{H}_{2} \mathrm{O}\right)_{6}$ (Bats et al., 1986), the coor-

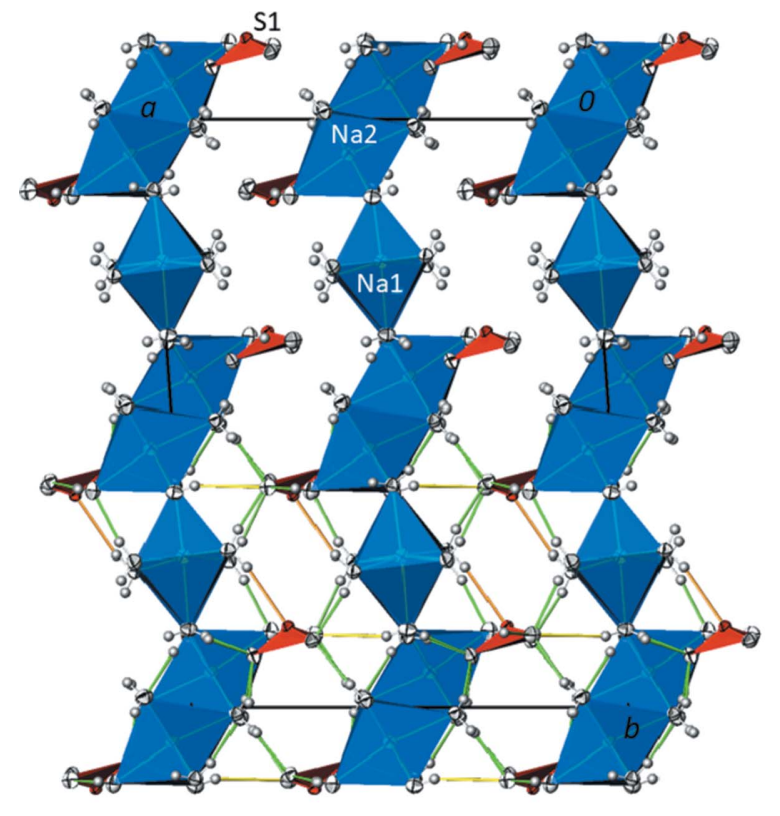

(a)

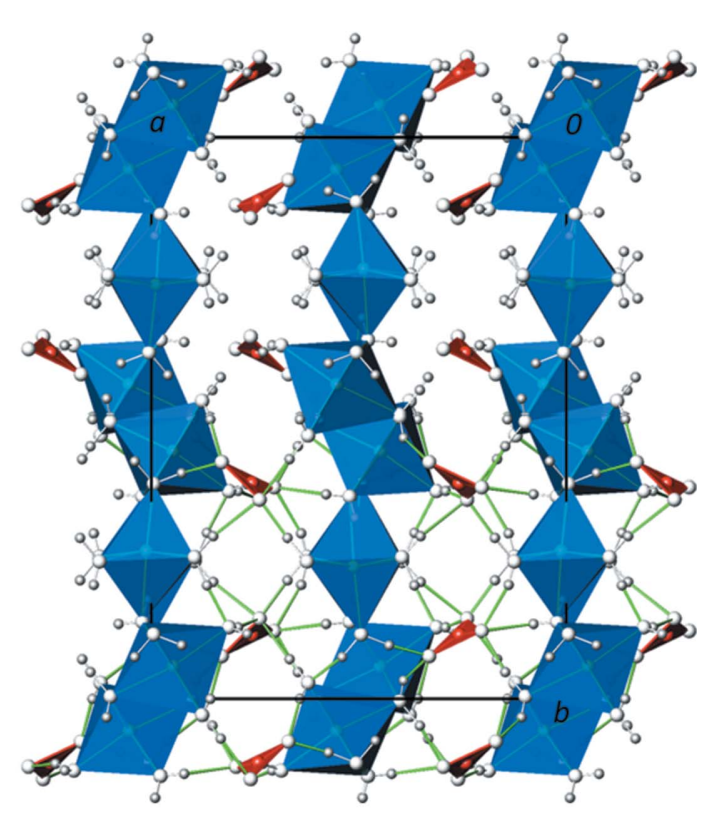

(b)

Figure 2

(a) The crystal structure of $\mathrm{Na}_{2} \mathrm{SO}_{3}\left(\mathrm{H}_{2} \mathrm{O}\right)_{7}$ in a projection along [001], showing the layered character with cationic water-sodium layers at $x \simeq 0$, $\frac{1}{2}$ alternating with sulfite layers (red polyhedra) at $x \simeq \frac{1}{4}, \frac{3}{4}$. (b) The crystal structure of $\mathrm{Na}_{2} \mathrm{CO}_{3}\left(\mathrm{H}_{2} \mathrm{O}\right)_{7}$ in a projection along [001], showing the same type of layer stacking but a different orientation of the dimeric groups and adjacent carbonate anions at $y \simeq \frac{1}{2}$. For clarity, hydrogen bonds are displayed only in the lower half of the figures, with moderate $\mathrm{O}-\mathrm{H} \cdots \mathrm{O}$ hydrogen bonds shown as green lines, weak $\mathrm{O}-\mathrm{H} \cdots \mathrm{O}$ bonds as yellow lines and $\mathrm{O}-\mathrm{H} \cdots \mathrm{S}$ hydrogen bonds as orange lines. 
dination capability of the sulfite $\mathrm{S}$ atom via its electron lonepair lobe at the apex of the $\mathrm{SO}_{3}$ pyramid is not unexpected, but this capability seems to be weak in the context of hydrogen bonding because otherwise more examples with features comparable to the title compound would have been encountered already. As soon as covalent bonding comes into play, the coordination capability of the sulfite $\mathrm{S}$ atom is well documented by transition-metal complexes like $\mathrm{K}_{2}[\mathrm{Pd}$ $\left.\left(\mathrm{SO}_{3}\right)_{2}\right] \cdot \mathrm{H}_{2} \mathrm{O}$ (Messer et al., 1979) or $\mathrm{K}_{2}\left[\mathrm{Hg}\left(\mathrm{SO}_{3}\right)_{2}\right] \cdot 2.25 \mathrm{H}_{2} \mathrm{O}$ (Weil et al., 2010), with metal-sulfur bonds, or by hydrogen sulfites like $\mathrm{CsHSO}_{3}$ (Johansson et al., 1980) or $\mathrm{K}_{5}\left(\mathrm{HSO}_{3}\right)$ $\left(\mathrm{S}_{2} \mathrm{O}_{5}\right)$ (Magnusson et al., 1983) that contain $\mathrm{HSO}_{3}{ }^{-}$anions with hydrogen covalently bonded to sulfur.

The numerical values of the atomic distances for crystalline $\mathrm{Na}_{2} \mathrm{SO}_{3}\left(\mathrm{H}_{2} \mathrm{O}\right)_{7}$ (Tables 3 and 4) are in good agreement with those of aqueous $\mathrm{Na}_{2} \mathrm{SO}_{3}$ solutions determined from LAXS studies, with $\mathrm{S}-\mathrm{O}=1.53 \AA$ for the sulfite group and $\mathrm{Na}-\mathrm{O}=$ $2.41 \AA$ for the sodium - water distances (Eklund et al., 2012). In the latter study, the $\mathrm{S} \cdots \mathrm{O}_{\text {water }}$ distance in solution was determined as $3.68 \AA$, which is considerably longer than in the solid state, giving further evidence for a weak but existing $\mathrm{O}-$ $\mathrm{H}$...S hydrogen bond in the crystalline material.

\subsection{Comparison with $\mathrm{Na}_{2} \mathrm{CO}_{3}\left(\mathrm{H}_{2} \mathrm{O}\right)_{7}$}

The close structural relationship between monoclinic $\mathrm{Na}_{2} \mathrm{SO}_{3}\left(\mathrm{H}_{2} \mathrm{O}\right)_{7}$ and orthorhombic $\mathrm{Na}_{2} \mathrm{CO}_{3}\left(\mathrm{H}_{2} \mathrm{O}\right)_{7}$ (Table 1) becomes evident from the similar arrangement of the principal building units in the crystal structures. The same type of cationic sodium-water layers made up from edge- and cornersharing $\left[\mathrm{Na}\left(\mathrm{H}_{2} \mathrm{O}\right)_{6}\right]$ octahedra [mean $\mathrm{Na}-\mathrm{O}$ distance = 2.43 (4) $\AA$ and $\mathrm{O}-\mathrm{Na}-\mathrm{O}$ angles $=81-102$ and $164-180^{\circ}$; Fig. $1 b]$ is present in the carbonate, likewise situated at $x \simeq 0, \frac{1}{2}$ in the unit cell (Fig. 2b). The carbonate groups do not show pyramidalization (Zemann, 1981) and occupy the same space as the sulfite groups between adjacent layers close to the $\left[\mathrm{Na}\left(\mathrm{H}_{2} \mathrm{O}\right)_{2 / 2}\left(\mathrm{H}_{2} \mathrm{O}\right)_{4 / 1}\right]_{2}$ dimers.

The main difference between the two structures is related to the orientation of the $\left[\mathrm{Na}\left(\mathrm{H}_{2} \mathrm{O}\right)_{2 / 2}\left(\mathrm{H}_{2} \mathrm{O}\right)_{4 / 1}\right]_{2}$ dimers in the layers. Whereas in the sulfite structure, the dimers at $y \simeq 0$ and $\frac{1}{2}$ in one layer and also the accompanying anions close to them have the same orientation relative to (100), in the carbonate structure, the orientation of every second dimer (at $y \simeq \frac{1}{2}$ ) and the accompanying anions in a layer is reversed due to the presence of the $c$-glide plane (Fig. 2).

The hydrogen-bonding schemes in the two heptahydrates are similar (Fig. 3). In the carbonate structure, the anions are likewise hydrogen bonded to water molecules through medium-strong hydrogen bonds $[\mathrm{O} \cdots \mathrm{O}=2.690(5)-$ 3.060 (4) $\AA$, with an additional weak interaction of $3.223(5) \AA]$. In analogy, two water-water $\mathrm{O}-\mathrm{H} \cdots \mathrm{O}$ interactions with donor-acceptor distances of 2.827 (5) and 2.766 (5) $\AA$ are also observed. However, in contrast to the central sulfite $\mathrm{S}$ atom with its free electron lone pair, the central $\mathrm{C}$ atom of the carbonate anion cannot act as a hydrogen-bond acceptor, and thus this interaction is missing in the carbonate structure.

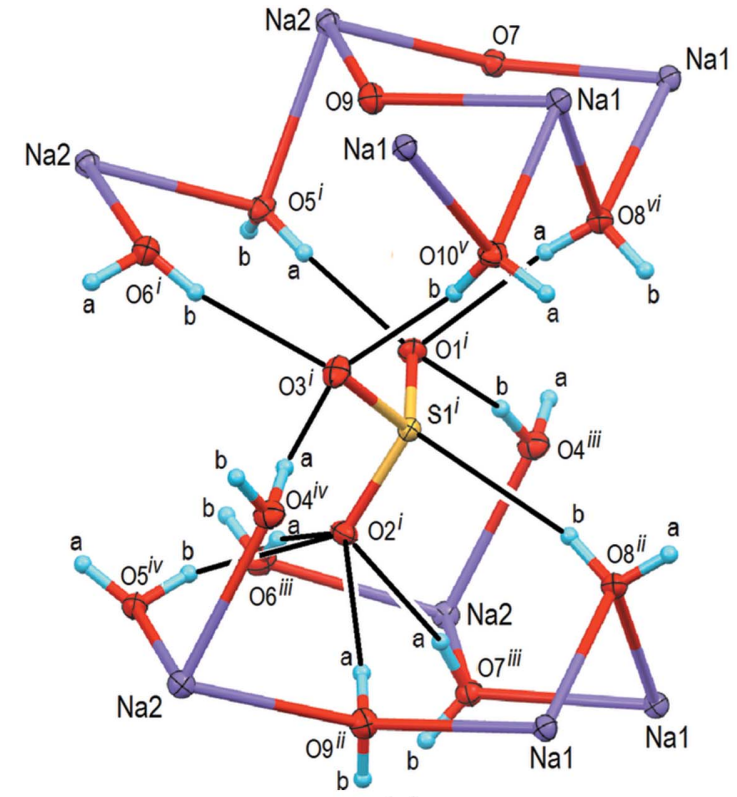

(a)

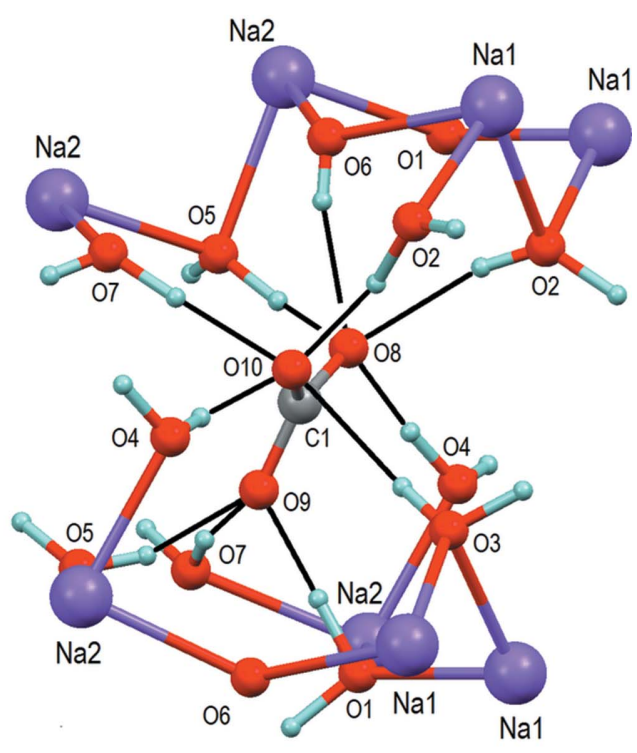

(b)

Figure 3

Comparison of the hydrogen bonding to the anion in $(a) \mathrm{Na}_{2} \mathrm{SO}_{3}\left(\mathrm{H}_{2} \mathrm{O}\right)_{7}$, with displacement ellipsoids drawn at the $50 \%$ probability level, and $(b)$ $\mathrm{Na}_{2} \mathrm{CO}_{3}\left(\mathrm{H}_{2} \mathrm{O}\right)_{7}$, with atoms as arbitrary spheres; hydrogen bonds are shown as thin solid lines. Atoms $\mathrm{O} 1$ and $\mathrm{O} 3$ in the sulfite structure accept three hydrogen bonds each, whereas $\mathrm{O} 8$ and $\mathrm{O} 10$ in the carbonate structure accept four each. Likewise, O2 in the sulfite structure accepts four hydrogen bonds, whereas the corresponding $\mathrm{O} 9$ atom in the carbonate accepts three. Note that the arrangement of the hydrogen-bonded water molecules around $\mathrm{SO}_{3}{ }^{2-}$ is approximately mirror-symmetric $\left(\right.$ e.g. $\mathrm{O}^{\mathrm{i}}$ and $\left.\mathrm{O}^{\mathrm{i}}\right)$, whereas it is less symmetric for the carbonate. Symmetry codes for atoms in $\mathrm{Na}_{2} \mathrm{SO}_{3}\left(\mathrm{H}_{2} \mathrm{O}\right)_{7}$ involved in hydrogen bonding with the $\mathrm{SO}_{3}^{2-}$ anion are: (i) $x, y, z$; (ii) $x+\frac{1}{2}, y-\frac{1}{2}, z$; (iii) $-x+\frac{3}{2},-y, z+\frac{1}{2}$; (iv) $-x+\frac{3}{2},-y, z-\frac{1}{2}$; (v) $-x+1,-y,-z+2$; (vi) $-x+1,-y,-z+3$. 


\subsection{Comparison with related compounds}

Crystal structures with sulfite groups anchored exclusively by hydrogen bonds are at present restricted to the title compound $\mathrm{Na}_{2} \mathrm{SO}_{3}\left(\mathrm{H}_{2} \mathrm{O}\right)_{7}$, to $\mathrm{NH}_{4} \mathrm{SO}_{3}\left(\mathrm{H}_{2} \mathrm{O}\right.$ ) (Battelle \& Trueblood, 1965; Durand et al., 1977) and to $\mathrm{MgSO}_{3}\left(\mathrm{H}_{2} \mathrm{O}\right)_{6}$ (Andersen \& Lindqvist, 1984; Bats et al., 1986). In $\mathrm{MgSO}_{3^{-}}$ $\left(\mathrm{H}_{2} \mathrm{O}\right)_{6}$, which is built up from $\left[\mathrm{Mg}\left(\mathrm{H}_{2} \mathrm{O}\right)_{6}\right]$ octahedra and isolated $\mathrm{SO}_{3}$ pyramids within a lattice of the space group type $R 3$, and with $\mathrm{Mg}$ and $\mathrm{S}$ atoms both located on threefold rotation axes, there are two independent water molecules that donate, apart from one water-water hydrogen bond, three water- $\mathrm{O}_{\text {sulfite }}$ hydrogen bonds to each sulfite $\mathrm{O}$ atom, comparable to $\mathrm{O} 1$ and $\mathrm{O} 3$ in $\mathrm{Na}_{2} \mathrm{SO}_{3}\left(\mathrm{H}_{2} \mathrm{O}\right)_{7}$, but with shorter O . . O distances [2.687 (3), 2.701 (3) and 2.726 (3) §] than in the latter. An electron deformation density study of $\mathrm{MgSO}_{3}\left(\mathrm{H}_{2} \mathrm{O}\right)_{6}$ (Bats et al., 1986) proved the presence of an extended lone-pair lobe at the apex of the $\mathrm{SO}_{3}$ pyramid, but neither $\mathrm{MgSO}_{3}\left(\mathrm{H}_{2} \mathrm{O}\right)_{6}$ nor $\mathrm{NH}_{4} \mathrm{SO}_{3}\left(\mathrm{H}_{2} \mathrm{O}\right)$ contain $\mathrm{O}-\mathrm{H} \cdots \mathrm{S}$ or $\mathrm{N}-\mathrm{H} \cdots \mathrm{S}$ hydrogen bonds.

A further comparison with other hydrated sodium compounds comprised of related oxo anions shows no close structural relationship to the title heptahydrate. For example, $\mathrm{Na}_{2} \mathrm{SO}_{4}\left(\mathrm{H}_{2} \mathrm{O}\right)_{7}$ (Oswald et al., 2008) (I4 / /amd, $Z=4$ ) has a completely different arrangement of the principal building units. Its crystal structure is comprised of $\left[\mathrm{Na}\left(\mathrm{H}_{2} \mathrm{O}\right)\right]_{6}$ octahedra concatenated by edge- and corner-sharing into a threedimensional network with isolated tetrahedral sulfate anions hydrogen bonded to the chains. Also, for sodium compounds with analogous trigonal-pyramidal oxoanions and the same charge, i.e. $\mathrm{XO}_{3}{ }^{2-}$, with $X=\mathrm{Se}$ and $\mathrm{Te}$, no phases related structurally or compositionally to $\mathrm{Na}_{2} \mathrm{SO}_{3}\left(\mathrm{H}_{2} \mathrm{O}\right)_{7}$ are known. For $\mathrm{Na}_{2} \mathrm{SeO}_{3}$, the anhydrous form $\left(P 2_{1} / c, Z=4\right)$ is made up from $\left[\mathrm{NaO}_{6}\right.$ ] octahedra and trigonal-pyramidal $\mathrm{SeO}_{3}{ }^{2-}$ anions (Wickleder, 2002), and is isotypic with $\mathrm{Na}_{2} \mathrm{TeO}_{3}$ (Masse et al., 1980). Hydrated forms are known only for the pentahydrates $\mathrm{Na}_{2} \mathrm{SeO}_{3}\left(\mathrm{H}_{2} \mathrm{O}\right)_{5}$ (Mereiter, 2013) and $\mathrm{Na}_{2} \mathrm{TeO}_{3}\left(\mathrm{H}_{2} \mathrm{O}\right)_{5}$ (Philippot et al., 1979) that are, surprisingly, not isotypic ( $P b c m$, with $Z=8$, and $C 2 / c$, with $Z=8$, respectively). These structures are based on two- or three-dimensional assemblies of $\left[\mathrm{NaO}_{5}\right]$ polyhedra $(\mathrm{Se})$ and $\left[\mathrm{NaO}_{6}\right]$ octahedra (Se and $\mathrm{Te}$ ), to which $\mathrm{SeO}_{3} / \mathrm{TeO}_{3}$ groups are bonded via two $(\mathrm{Se})$ or one (Te) $\mathrm{O}$ atom. The $\left[\mathrm{NaO}_{6}\right]$ octahedra in these two salts share common faces and edges but no vertices. As pointed out by Philippot et al. (1979) for $\mathrm{Na}_{2} \mathrm{TeO}_{3}\left(\mathrm{H}_{2} \mathrm{O}\right)_{5}$ and confirmed also for $\mathrm{Na}_{2} \mathrm{SeO}_{3}\left(\mathrm{H}_{2} \mathrm{O}\right)_{5}$ (Mereiter, 2013), the electron lone pair of $\mathrm{Se}$ and $\mathrm{Te}$ in these structures shows no attracting interactions with neighbouring $\mathrm{H}$ atoms. This might be one reason why hydrates of $\mathrm{Na}_{2} \mathrm{SeO}_{3}$ and $\mathrm{Na}_{2} \mathrm{TeO}_{3}$ do not crystallize in the $\mathrm{Na}_{2} \mathrm{SO}_{3}\left(\mathrm{H}_{2} \mathrm{O}\right)_{7}$ structure and vice versa.

\section{Acknowledgements}

The X-ray centre of TU Wien is acknowledged for providing access to the single-crystal X-ray diffractometer.

\section{References}

Allen, F. H., Bird, C. M., Rowland, R. S. \& Raithby, P. R. (1997). Acta Cryst. B53, 696-701.

Andersen, L. \& Lindqvist, O. (1984). Acta Cryst. C40, 584-586.

Battelle, L. F. \& Trueblood, K. N. (1965). Acta Cryst. 19, 531-535.

Bats, J. W., Fuess, H. \& Elerman, Y. (1986). Acta Cryst. B42, 552557.

Betzel, C., Saenger, W. \& Loewus, D. (1982). Acta Cryst. B38, 28022804.

Brese, N. E. \& O'Keeffe, M. (1991). Acta Cryst. B47, 192-197.

Brown, I. D. (2002). In The Chemical Bond in Inorganic Chemistry: The Bond Valence Model. Oxford University Press.

Bruker (2014). APEX2 and SAINT. Bruker AXS Inc., Madison, Wisconsin, USA.

Dowty, E. (2006). ATOMS. Shape Software, Kingsport, Tennessee, USA.

Dunsmore, H. S. \& Speakman, J. C. (1963). Acta Cryst. 16, 573574.

Durand, J., Galigné, J. L. \& Cot, L. (1977). Acta Cryst. B33, 14141417.

Eklund, L., Hofer, T. S., Pribil, A. B., Rode, B. M. \& Persson, I. (2012). Dalton Trans. 41, 5209-5216.

Gagné, O. C. \& Hawthorne, F. C. (2016). Acta Cryst. B72, 602625.

Gagné, O. C. \& Hawthorne, F. C. (2018). Acta Cryst. B74, 79-96.

Groom, C. R., Bruno, I. J., Lightfoot, M. P. \& Ward, S. C. (2016). Acta Cryst. B72, 171-179.

Jeffrey, G. A. (1997). In An Introduction to Hydrogen Bonding. New York: Oxford University Press Inc.

Johansson, L.-G., Lindqvist, O. \& Vannerberg, N.-G. (1980). Acta Cryst. B36, 2523-2526.

Krause, L., Herbst-Irmer, R., Sheldrick, G. M. \& Stalke, D. (2015). J. Appl. Cryst. 48, 3-10.

Larsson, L. O. \& Kierkegaard, P. (1969). Acta Chem. Scand. 23, $2253-$ 2260.

Macrae, C. F., Sovago, I., Cottrell, S. J., Galek, P. T. A., McCabe, P., Pidcock, E., Platings, M., Shields, G. P., Stevens, J. S., Towler, M. \& Wood, P. A. (2020). J. Appl. Cryst. 53, 226-235.

Magnusson, A., Johansson, L.-G. \& Lindqvist, O. (1983). Acta Cryst. C39, 819-822.

Manojlović-Muir, L. (1969). Nature, 224, 686-687.

Masse, R., Guitel, J. C. \& Tordjman, I. (1980). Mater. Res. Bull. 15, 431-436.

Mereiter, K. (2013). Acta Cryst. E69, i77-i78.

Messer, D., Breitinger, D. \& Haegler, W. (1979). Acta Cryst. B35, 815818.

Mikenda, W., Mereiter, K. \& Preisinger, A. (1989). Inorg. Chim. Acta, 161, 21-28.

Nyberg, B. \& Larsson, R. (1973). Acta Chem. Scand. 27, 63-70.

Oswald, I. D. H., Hamilton, A., Hall, C., Marshall, W. G., Prior, T. J. \& Pulham, C. R. (2008). J. Am. Chem. Soc. 130, 17795-17800.

Philippot, E., Maurin, M. \& Moret, J. (1979). Acta Cryst. B35, 13371340.

Sheldrick, G. M. (2015a). Acta Cryst. A71, 3-8.

Sheldrick, G. M. (2015b). Acta Cryst. C71, 3-8.

Weil, E. D., Sandler, S. R. \& Gernon, M. (2007). Sulfur Compounds, 13.1 Sodium Sulfite. In Kirk-Othmer Concise Encyclopedia of Chemical Technology, 5th ed., Vol. 23, edited by A. Seidel, pp. 669672. New York: John Wiley \& Sons Inc.

Weil, M., Baumann, S. O. \& Breitinger, D. K. (2010). Acta Cryst. C66, i89-i91.

Westrip, S. P. (2010). J. Appl. Cryst. 43, 920-925.

Wickleder, M. S. (2002). Acta Cryst. E58, i103-i104.

Zemann, J. (1981). Fortschr. Mineral. 59, 95-116. 


\section{supporting information}

Acta Cryst. (2020). C76, 427-432 [https://doi.org/10.1107/S2053229620004404]

Sodium sulfite heptahydrate and its relation to sodium carbonate heptahydrate

\section{Matthias Weil and Kurt Mereiter}

\section{Computing details}

Data collection: APEX2 (Bruker, 2014); cell refinement: SAINT (Bruker, 2014); data reduction: SAINT (Bruker, 2014); program(s) used to solve structure: SHELXT (Sheldrick, 2015a); program(s) used to refine structure: SHELXL2018 (Sheldrick, 2015b); molecular graphics: ATOMS (Dowty, 2006) and Mercury (Macrae et al., 2020); software used to prepare material for publication: publCIF (Westrip, 2010).

Sodium sulfite heptahydrate

Crystal data

$\mathrm{H}_{14} \mathrm{Na}_{2} \mathrm{O}_{10} \mathrm{~S}$

$M_{r}=252.15$

Monoclinic, $C 112_{1} / a$

Hall symbol: $-\mathrm{C} \_2 \mathrm{ac}$

$a=14.6563(8) \bar{\AA}$

$b=19.7180(9) \AA$

$c=7.2197(5) \AA$

$\beta=90^{\circ}$

$V=2081.1(2) \AA^{3}$

$Z=8$

\section{Data collection}

Bruker APEXII CCD diffractometer

Radiation source: fine-focus sealed tube $\omega$ - and $\varphi$-scan

Absorption correction: multi-scan

(SADABS; Krause et al., 2015)

$T_{\min }=0.675, T_{\max }=0.747$

16909 measured reflections

\section{Refinement}

Refinement on $F^{2}$

Least-squares matrix: full

$R\left[F^{2}>2 \sigma\left(F^{2}\right)\right]=0.023$

$w R\left(F^{2}\right)=0.063$

$S=1.06$

4845 reflections

174 parameters

0 restraints
$F(000)=1056$

$D_{\mathrm{x}}=1.610 \mathrm{Mg} \mathrm{m}^{-3}$

Mo $K \alpha$ radiation, $\lambda=0.71073 \AA$

Cell parameters from 8292 reflections

$\theta=2.8-36.0^{\circ}$

$\mu=0.42 \mathrm{~mm}^{-1}$

$T=100 \mathrm{~K}$

Fragment, colourless

$0.15 \times 0.13 \times 0.12 \mathrm{~mm}$

4845 independent reflections 4222 reflections with $I>2 \sigma(I)$

$R_{\text {int }}=0.021$

$\theta_{\max }=36.0^{\circ}, \theta_{\min }=2.8^{\circ}$

$h=-24 \rightarrow 23$

$k=-32 \rightarrow 30$

$l=-11 \rightarrow 11$

Hydrogen site location: difference Fourier map

All $\mathrm{H}$-atom parameters refined

$w=1 /\left[\sigma^{2}\left(F_{\mathrm{o}}^{2}\right)+(0.0304 P)^{2}+0.806 P\right]$ where $P=\left(F_{\mathrm{o}}^{2}+2 F_{\mathrm{c}}^{2}\right) / 3$

$(\Delta / \sigma)_{\max }=0.003$

$\Delta \rho_{\max }=0.89 \mathrm{e} \AA^{-3}$

$\Delta \rho_{\min }=-0.33$ e $\AA^{-3}$ 


\section{Special details}

Geometry. All esds (except the esd in the dihedral angle between two 1.s. planes) are estimated using the full covariance matrix. The cell esds are taken into account individually in the estimation of esds in distances, angles and torsion angles; correlations between esds in cell parameters are only used when they are defined by crystal symmetry. An approximate (isotropic) treatment of cell esds is used for estimating esds involving l.s. planes.

Fractional atomic coordinates and isotropic or equivalent isotropic displacement parameters $\left(\AA^{2}\right)$

\begin{tabular}{lllll}
\hline & $x$ & $y$ & $z$ & $U_{\text {iso }} / U_{\text {eq }}$ \\
\hline Na1 & $0.49508(2)$ & $0.24227(2)$ & $1.10868(4)$ & $0.00970(6)$ \\
Na2 & $0.55111(2)$ & $0.06011(2)$ & $1.35665(4)$ & $0.01015(6)$ \\
S1 & $0.76676(2)$ & $-0.13751(2)$ & $1.37190(2)$ & $0.00782(4)$ \\
O1 & $0.71232(3)$ & $-0.11448(2)$ & $1.53732(7)$ & $0.01115(8)$ \\
O2 & $0.85230(3)$ & $-0.08810(3)$ & $1.36082(6)$ & $0.01132(8)$ \\
O3 & $0.70978(4)$ & $-0.12350(3)$ & $1.20165(7)$ & $0.01248(9)$ \\
O4 & $0.69179(4)$ & $0.12961(3)$ & $1.36691(7)$ & $0.01302(9)$ \\
O5 & $0.60016(4)$ & $-0.01074(3)$ & $1.59875(7)$ & $0.01119(8)$ \\
O6 & $0.60771(4)$ & $-0.01777(3)$ & $1.11731(7)$ & $0.01330(9)$ \\
O7 & $0.50388(4)$ & $0.12044(3)$ & $1.08692(7)$ & $0.01129(8)$ \\
O8 & $0.39237(4)$ & $0.23269(3)$ & $1.36393(7)$ & $0.01119(8)$ \\
O9 & $0.49463(4)$ & $0.36695(3)$ & $1.11835(7)$ & $0.01244(9)$ \\
O10 & $0.39308(4)$ & $0.24819(3)$ & $0.85559(7)$ & $0.01182(9)$ \\
H4A & $0.7253(10)$ & $0.1272(7)$ & $1.454(2)$ & $0.040(4)^{*}$ \\
H4B & $0.7270(10)$ & $0.1258(7)$ & $1.280(2)$ & $0.043(4)^{*}$ \\
H5A & $0.6351(9)$ & $-0.0397(7)$ & $1.5804(18)$ & $0.026(3)^{*}$ \\
H5B & $0.6230(10)$ & $0.0138(7)$ & $1.6763(19)$ & $0.036(4)^{*}$ \\
H6A & $0.6299(9)$ & $0.0083(7)$ & $1.047(2)$ & $0.035(4)^{*}$ \\
H6B & $0.6429(10)$ & $-0.0432(8)$ & $1.1470(18)$ & $0.033(4)^{*}$ \\
H7A & $0.5492(9)$ & $0.1157(6)$ & $1.0255(19)$ & $0.030(3)^{*}$ \\
H7B & $0.4660(10)$ & $0.0941(7)$ & $1.053(2)$ & $0.034(4)^{*}$ \\
H8A & $0.3667(10)$ & $0.1966(7)$ & $1.3816(17)$ & $0.032(4)^{*}$ \\
H8B & $0.3519(10)$ & $0.2597(7)$ & $1.3636(16)$ & $0.026(3)^{*}$ \\
H9A & $0.4574(10)$ & $0.3785(7)$ & $1.192(2)$ & $0.030(3)^{*}$ \\
H9B & $0.5427(11)$ & $0.3788(7)$ & $1.1579(19)$ & $0.034(4)^{*}$ \\
H10A & $0.3612(10)$ & $0.2819(8)$ & $0.8574(17)$ & $0.032(4)^{*}$ \\
H10B & $0.3596(10)$ & $0.2171(7)$ & $0.8447(17)$ & $0.026(3)^{*}$ \\
& & & &
\end{tabular}

Atomic displacement parameters $\left(\AA^{2}\right)$

\begin{tabular}{lllllll}
\hline & $U^{11}$ & $U^{22}$ & $U^{33}$ & $U^{12}$ & $U^{13}$ & $U^{23}$ \\
\hline $\mathrm{Na} 1$ & $0.01001(12)$ & $0.01018(12)$ & $0.00894(11)$ & $0.00089(9)$ & $-0.00002(8)$ & $0.00018(8)$ \\
$\mathrm{Na} 2$ & $0.01087(13)$ & $0.01032(12)$ & $0.00923(11)$ & $0.00053(9)$ & $-0.00029(8)$ & $0.00100(8)$ \\
$\mathrm{S} 1$ & $0.00777(6)$ & $0.00762(6)$ & $0.00812(6)$ & $0.00102(4)$ & $-0.00010(4)$ & $0.00042(4)$ \\
$\mathrm{O} 1$ & $0.0113(2)$ & $0.0120(2)$ & $0.01032(18)$ & $0.00238(16)$ & $0.00291(14)$ & $-0.00012(14)$ \\
$\mathrm{O} 2$ & $0.0090(2)$ & $0.0124(2)$ & $0.01216(19)$ & $-0.00153(16)$ & $0.00037(14)$ & $0.00118(15)$ \\
O3 & $0.0144(2)$ & $0.0131(2)$ & $0.01010(19)$ & $0.00150(17)$ & $-0.00474(15)$ & $0.00016(15)$ \\
O4 & $0.0119(2)$ & $0.0158(2)$ & $0.0114(2)$ & $0.00138(17)$ & $0.00043(16)$ & $0.00018(16)$ \\
O5 & $0.0113(2)$ & $0.0101(2)$ & $0.01232(19)$ & $0.00204(16)$ & $-0.00185(15)$ & $-0.00181(15)$
\end{tabular}


supporting information

\begin{tabular}{lllllll} 
O6 & $0.0132(2)$ & $0.0122(2)$ & $0.0147(2)$ & $0.00227(17)$ & $0.00056(16)$ & $0.00217(16)$ \\
O7 & $0.0112(2)$ & $0.0112(2)$ & $0.01143(19)$ & $0.00058(16)$ & $0.00061(15)$ & $-0.00022(15)$ \\
O8 & $0.0099(2)$ & $0.0104(2)$ & $0.01337(19)$ & $0.00126(16)$ & $0.00133(15)$ & $0.00157(15)$ \\
O9 & $0.0139(2)$ & $0.0117(2)$ & $0.01171(19)$ & $0.00068(17)$ & $0.00033(16)$ & $-0.00053(15)$ \\
O10 & $0.0101(2)$ & $0.0117(2)$ & $0.0136(2)$ & $0.00013(17)$ & $-0.00087(15)$ & $-0.00148(15)$ \\
\hline
\end{tabular}

Geometric parameters $\left(A,{ }^{\circ}\right)$

\begin{tabular}{|c|c|c|c|}
\hline $\mathrm{Na} 1-\mathrm{O} 10$ & $2.3690(6)$ & $\mathrm{Na} 2-\mathrm{O} 4$ & $2.3939(6)$ \\
\hline $\mathrm{Na} 1-\mathrm{O} 8$ & $2.3785(6)$ & $\mathrm{Na} 2-\mathrm{O} 7$ & $2.4093(6)$ \\
\hline $\mathrm{Na} 1-\mathrm{O} 10^{\mathrm{i}}$ & $2.4199(6)$ & $\mathrm{Na} 2-\mathrm{O} 6$ & $2.4928(6)$ \\
\hline $\mathrm{Na} 1-\mathrm{O} 7$ & $2.4199(6)$ & $\mathrm{Na} 2-\mathrm{O} 9^{\mathrm{i}}$ & $2.4952(6)$ \\
\hline $\mathrm{Na} 1-\mathrm{O} 8^{\mathrm{ii}}$ & $2.4436(6)$ & $\mathrm{S} 1-\mathrm{O} 3$ & $1.5224(5)$ \\
\hline $\mathrm{Na} 1-\mathrm{O} 9$ & $2.4599(6)$ & $\mathrm{S} 1-\mathrm{O} 1$ & $1.5234(5)$ \\
\hline $\mathrm{Na} 2-\mathrm{O} 5^{\mathrm{iii}}$ & $2.3787(6)$ & $\mathrm{S} 1-\mathrm{O} 2$ & $1.5338(5)$ \\
\hline $\mathrm{Na} 2-\mathrm{O} 5$ & $2.3805(6)$ & & \\
\hline $\mathrm{O} 5{ }^{\mathrm{iii}}-\mathrm{Na} 2-\mathrm{O} 5$ & $88.41(2)$ & $\mathrm{H} 4 \mathrm{~A}-\mathrm{O} 4-\mathrm{H} 4 \mathrm{~B}$ & $101.7(15)$ \\
\hline $\mathrm{O}^{\mathrm{iii}-\mathrm{Na} 2-\mathrm{O} 4}$ & $165.81(2)$ & $\mathrm{Na} 22^{\mathrm{iii}}-\mathrm{O} 5-\mathrm{Na} 2$ & $91.59(2)$ \\
\hline $\mathrm{O} 5-\mathrm{Na} 2-\mathrm{O} 4$ & $91.68(2)$ & $\mathrm{Na} 2{ }^{\mathrm{iii}}-\mathrm{O} 5-\mathrm{H} 5 \mathrm{~A}$ & $110.7(9)$ \\
\hline $\mathrm{O} 5{ }^{\mathrm{iii}}-\mathrm{Na} 2-\mathrm{O} 7$ & $91.10(2)$ & $\mathrm{Na} 2-\mathrm{O} 5-\mathrm{H} 5 \mathrm{~A}$ & $122.0(9)$ \\
\hline $\mathrm{O} 5-\mathrm{Na} 2-\mathrm{O} 7$ & $173.08(2)$ & 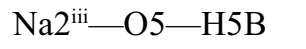 & $119.4(10)$ \\
\hline $\mathrm{O} 4-\mathrm{Na} 2-\mathrm{O} 7$ & $90.48(2)$ & $\mathrm{Na} 2-\mathrm{O} 5-\mathrm{H} 5 \mathrm{~B}$ & $106.9(10)$ \\
\hline $\mathrm{O} 5{ }^{\mathrm{iii}}-\mathrm{Na} 2-\mathrm{O} 6$ & $100.56(2)$ & $\mathrm{H} 5 \mathrm{~A}-\mathrm{O} 5-\mathrm{H} 5 \mathrm{~B}$ & $106.6(14)$ \\
\hline $\mathrm{O} 5-\mathrm{Na} 2-\mathrm{O} 6$ & $91.13(2)$ & $\mathrm{Na} 2-\mathrm{O} 6-\mathrm{H} 6 \mathrm{~A}$ & $100.9(10)$ \\
\hline $\mathrm{O} 4-\mathrm{Na} 2-\mathrm{O} 6$ & $93.62(2)$ & $\mathrm{Na} 2-\mathrm{O} 6-\mathrm{H} 6 \mathrm{~B}$ & $118.2(10)$ \\
\hline $\mathrm{O} 7-\mathrm{Na} 2-\mathrm{O} 6$ & $82.177(19)$ & $\mathrm{H} 6 \mathrm{~A}-\mathrm{O} 6-\mathrm{H} 6 \mathrm{~B}$ & $110.0(14)$ \\
\hline $\mathrm{O} 5^{\mathrm{iii}}-\mathrm{Na} 2-\mathrm{O} 9^{\mathrm{i}}$ & $81.51(2)$ & $\mathrm{Na} 2-\mathrm{O} 7-\mathrm{Na} 2$ & $118.38(2)$ \\
\hline $\mathrm{O} 5-\mathrm{Na} 2-\mathrm{O}^{\mathrm{i}}$ & $83.523(19)$ & $\mathrm{Na} 2-\mathrm{O} 7-\mathrm{H} 7 \mathrm{~A}$ & $96.9(9)$ \\
\hline $\mathrm{O} 4-\mathrm{Na} 2-\mathrm{O}^{\mathrm{i}}$ & $84.40(2)$ & $\mathrm{Na} 1-\mathrm{O} 7-\mathrm{H} 7 \mathrm{~A}$ & $104.6(9)$ \\
\hline $\mathrm{O} 7-\mathrm{Na} 2-\mathrm{O}^{\mathrm{i}}$ & $103.23(2)$ & $\mathrm{Na} 2-\mathrm{O} 7-\mathrm{H} 7 \mathrm{~B}$ & $98.3(10)$ \\
\hline $\mathrm{O} 6-\mathrm{Na} 2-\mathrm{O}^{\mathrm{i}}$ & $174.23(2)$ & $\mathrm{Na} 1-\mathrm{O} 7-\mathrm{H} 7 \mathrm{~B}$ & $127.0(10)$ \\
\hline $\mathrm{O} 10-\mathrm{Na} 1-\mathrm{O} 8$ & $101.74(2)$ & $\mathrm{H} 7 \mathrm{~A}-\mathrm{O} 7-\mathrm{H} 7 \mathrm{~B}$ & $107.6(13)$ \\
\hline $\mathrm{O} 10-\mathrm{Na} 1-\mathrm{O} 10^{\mathrm{i}}$ & $172.170(15)$ & $\mathrm{Na} 1-\mathrm{O} 8-\mathrm{Na}^{\mathrm{i}}$ & 97.465 (19) \\
\hline $\mathrm{O} 8-\mathrm{Na} 1-\mathrm{O} 10^{\mathrm{i}}$ & $81.77(2)$ & $\mathrm{Na} 1-\mathrm{O} 8-\mathrm{H} 8 \mathrm{~A}$ & $117.0(9)$ \\
\hline $\mathrm{O} 10-\mathrm{Na} 1-\mathrm{O} 7$ & $94.44(2)$ & $\mathrm{Na} 1-\mathrm{O} 8-\mathrm{H} 8 \mathrm{~A}$ & $109.6(9)$ \\
\hline $\mathrm{O} 8-\mathrm{Na} 1-\mathrm{O} 7$ & $92.86(2)$ & $\mathrm{Na} 1-\mathrm{O} 8-\mathrm{H} 8 \mathrm{~B}$ & $115.3(8)$ \\
\hline 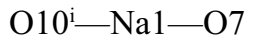 & $92.36(2)$ & $\mathrm{Na} 1-\mathrm{O} 8-\mathrm{H} 8 \mathrm{~B}$ & $112.2(9)$ \\
\hline $\mathrm{O} 10-\mathrm{Na} 1-\mathrm{O} 8^{\mathrm{ii}}$ & $81.464(19)$ & $\mathrm{H} 8 \mathrm{~A}-\mathrm{O} 8-\mathrm{H} 8 \mathrm{~B}$ & $105.3(14)$ \\
\hline $\mathrm{O} 8-\mathrm{Na} 1-\mathrm{O} 8^{\mathrm{ii}}$ & $172.149(16)$ & $\mathrm{Na} 1-\mathrm{O} 9-\mathrm{Na} 2^{\mathrm{ii}}$ & $125.08(2)$ \\
\hline $\mathrm{O} 10^{\mathrm{i}}-\mathrm{Na} 1-\mathrm{O} 8^{\mathrm{ii}}$ & $94.20(2)$ & $\mathrm{Na} 1-\mathrm{O} 9-\mathrm{H} 9 \mathrm{~A}$ & $110.5(10)$ \\
\hline $\mathrm{O} 7-\mathrm{Na} 1-\mathrm{O} 8^{\mathrm{ii}}$ & $94.04(2)$ & $\mathrm{Na} 2^{\mathrm{ii}}-\mathrm{O} 9-\mathrm{H} 9 \mathrm{~A}$ & $97.1(10)$ \\
\hline $\mathrm{O} 10-\mathrm{Na} 1-\mathrm{O} 9$ & $85.75(2)$ & $\mathrm{Na} 1-\mathrm{O} 9-\mathrm{H} 9 \mathrm{~B}$ & $104.1(11)$ \\
\hline $\mathrm{O} 8-\mathrm{Na} 1-\mathrm{O} 9$ & $90.60(2)$ & $\mathrm{Na} 2^{\mathrm{ii}}-\mathrm{O} 9-\mathrm{H} 9 \mathrm{~B}$ & $112.2(11)$ \\
\hline $\mathrm{O} 10^{\mathrm{i}}-\mathrm{Na} 1-\mathrm{O} 9$ & $87.22(2)$ & $\mathrm{H} 9 \mathrm{~A}-\mathrm{O} 9-\mathrm{H} 9 \mathrm{~B}$ & $106.7(14)$ \\
\hline $\mathrm{O} 7-\mathrm{Na} 1-\mathrm{O} 9$ & $176.42(2)$ & $\mathrm{Na} 1-\mathrm{O} 10-\mathrm{Na} 1^{\mathrm{ii}}$ & $98.38(2)$ \\
\hline $\mathrm{O} 8^{\mathrm{ii}}-\mathrm{Na} 1-\mathrm{O} 9$ & $82.451(19)$ & $\mathrm{Na} 1-\mathrm{O} 10-\mathrm{H} 10 \mathrm{~A}$ & $114.6(9)$ \\
\hline $\mathrm{O} 3-\mathrm{S} 1-\mathrm{O} 1$ & $105.85(3)$ & $\mathrm{Na} 1^{\mathrm{ii}}-\mathrm{O} 10-\mathrm{H} 10 \mathrm{~A}$ & $111.2(9)$ \\
\hline
\end{tabular}




$\begin{array}{llll}\mathrm{O} 3-\mathrm{S} 1-\mathrm{O} 2 & 106.07(3) & \mathrm{Na} 1-\mathrm{O} 10-\mathrm{H} 10 \mathrm{~B} & 114.4(10) \\ \mathrm{O} 1-\mathrm{S} 1-\mathrm{O} 2 & 105.87(3) & \mathrm{Na} 1 \mathrm{ii}-\mathrm{O} 10-\mathrm{H} 10 \mathrm{~B} & 112.4(9) \\ \mathrm{Na} 2-\mathrm{O} 4-\mathrm{H} 4 \mathrm{~A} & 119.9(11) & \mathrm{H} 10 \mathrm{~A}-\mathrm{O} 10-\mathrm{H} 10 \mathrm{~B} & 106.0(14) \\ \mathrm{Na} 2-\mathrm{O} 4-\mathrm{H} 4 \mathrm{~B} & 116.4(11) & & \end{array}$

Symmetry codes: (i) $-x+1,-y+1 / 2, z+1 / 2$; (ii) $-x+1,-y+1 / 2, z-1 / 2$; (iii) $-x+1,-y,-z+3$.

Hydrogen-bond geometry $\left(\AA,{ }^{\circ}\right)$

\begin{tabular}{lllll}
\hline$D-\mathrm{H} \cdots A$ & $D-\mathrm{H}$ & $\mathrm{H} \cdots A$ & $D \cdots A$ & $D-\mathrm{H}^{\cdots} A$ \\
\hline $\mathrm{O} 4-\mathrm{H} 4 A \cdots \mathrm{O} 3^{\text {iv }}$ & $0.800(15)$ & $2.031(16)$ & $2.8216(8)$ & $169.7(15)$ \\
$\mathrm{O} 4-\mathrm{H} 4 B \cdots \mathrm{O} 1^{\mathrm{v}}$ & $0.821(16)$ & $1.983(16)$ & $2.7904(7)$ & $167.8(15)$ \\
$\mathrm{O} 5-\mathrm{H} 5 A \cdots \mathrm{O} 1$ & $0.804(13)$ & $1.947(13)$ & $2.7503(7)$ & $175.9(13)$ \\
$\mathrm{O} 5-\mathrm{H} 5 B \cdots \mathrm{O} 2^{\text {iv }}$ & $0.798(15)$ & $1.994(15)$ & $2.7694(7)$ & $163.9(15)$ \\
$\mathrm{O} 6-\mathrm{H} 6 A \cdots \mathrm{O} 2^{\mathrm{v}}$ & $0.777(14)$ & $2.072(14)$ & $2.8206(7)$ & $161.8(14)$ \\
$\mathrm{O} 6-\mathrm{H} 6 B \cdots \mathrm{O} 3$ & $0.774(15)$ & $1.962(15)$ & $2.7204(7)$ & $166.5(15)$ \\
$\mathrm{O} 7-\mathrm{H} 7 A \cdots \mathrm{O} 2^{\mathrm{v}}$ & $0.810(13)$ & $1.976(14)$ & $2.7761(7)$ & $169.3(13)$ \\
$\mathrm{O} 7-\mathrm{H} 7 B \cdots 6^{\text {vi }}$ & $0.773(14)$ & $2.171(14)$ & $2.9110(8)$ & $160.7(15)$ \\
$\mathrm{O} 8-\mathrm{H} 8 A \cdots \mathrm{O} 1^{\text {iii }}$ & $0.792(15)$ & $2.009(15)$ & $2.7900(7)$ & $168.9(13)$ \\
$\mathrm{O} 8-\mathrm{H} 8 B \cdots 1^{\text {vii }}$ & $0.825(14)$ & $2.455(14)$ & $3.2582(6)$ & $164.5(13)$ \\
$\mathrm{O} 9-\mathrm{H} 9 A \cdots \mathrm{O} 2^{\text {vii }}$ & $0.807(14)$ & $2.106(14)$ & $2.9096(7)$ & $174.0(14)$ \\
$\mathrm{O} 10-\mathrm{H} 10 A \cdots \mathrm{O} 4^{\text {ii }}$ & $0.839(15)$ & $1.962(15)$ & $2.7908(8)$ & $169.5(14)$ \\
$\mathrm{O} 10-\mathrm{H} 10 B \cdots \mathrm{O} 3^{\text {vi }}$ & $0.762(14)$ & $2.069(14)$ & $2.8210(7)$ & $169.1(14)$ \\
\end{tabular}

Symmetry codes: (ii) $-x+1,-y+1 / 2, z-1 / 2$; (iii) $-x+1,-y,-z+3$; (iv) $-x+3 / 2,-y, z+1 / 2$; (v) $-x+3 / 2,-y, z-1 / 2$; (vi) $-x+1,-y,-z+2$; (vii) $x-1 / 2, y+1 / 2, z$. 